\title{
Socio-medical characteristics of patients attending a V.D. clinic and the circumstances of infection
}

\author{
J. PEMBERTON,* J. S. McCANN, J. D. H. MAHONY, $†$ G. MacKENZIE,* \\ H. DOUGAN, $\dagger$ AND I. HAY * \\ From the Department of Social and Preventive Medicine, ${ }^{\star}$ Queen's University, and the Department of \\ Venereology, Royal Victoria Hospital, $†$ Belfast
}

The following study included all the patients attending the V.D. clinic at the Royal Victoria Hospital, Belfast, for the first time over a period of one year and its aim was to find out more about the social characteristics of the patients attending the clinic and the circumstances in which infection or suspected infection took place. It was hoped that the findings might point to more effective case finding and prevention.

\section{Methods}

A pre-coded questionnaire was completed for all new patients seen in 1969 and the data were punched on 80 -column cards for mechanical sorting.

\section{Results}

DIAGNOSES

Table I shows the distribution of the 2,093 diagnoses among the 1,753 patients who attended.

Received for publication May 16, 1972
In males, 'non-gonococcal urethritis' (NGU) was the commonest diagnosis (29 per cent.), followed by 'no disease found' (Nil) (25 per cent.) and gonorrhoea (G) (19 per cent.). In females 'Nil' was the commonest finding ( 25 per cent.), followed by candidiasis (Cand) (21 per cent.), non-gonococcal vaginitis (NGV) (15 per cent.), diagnosed mainly by inference in contacts of men with NGU, and gonorrhoea (13 per cent.). Syphilis in all forms accounted for only a small percentage of diagnoses: 3.9 per cent. in males and $2 \cdot 3$ per cent. in females. The relatively small proportion of diagnoses of the classical venereal diseases, especially syphilis, is noteworthy and also the frequency of NGU in males and candidiasis in females.

Other conditions of the genital organs (12 per cent.) consisted mainly of genital warts, balanitis, and cervical erosion.

\section{AGE AND SEX}

The peak incidence of cases was found in the 20 to 34-year age groups. Approximately two-thirds of the patients fell in these age groups compared with

TABLE I Distribution of the 2,093 diagnoses in 1,753 patients

\begin{tabular}{|c|c|c|c|c|c|}
\hline \multirow{2}{*}{ Diagnosis } & & \multicolumn{2}{|l|}{ Males } & \multicolumn{2}{|c|}{ Females } \\
\hline & & No. & Per cent. & No. & Per cent. \\
\hline Primary syphilis & S1 & 15 & $1 \cdot 1$ & 0 & \\
\hline Secondary syphilis & S2 & 9 & 0.7 & 3 & 0.4 \\
\hline Tertiary syphilis & S3 & 24 & $1 \cdot 8$ & 9 & $1 \cdot 2$ \\
\hline Congenital syphilis & $\mathrm{CS}$ & 4 & 0.3 & 5 & 0.7 \\
\hline Gonorrhoea & G & 256 & $18 \cdot 9$ & 97 & $13 \cdot 1$ \\
\hline Non-gonococcal urethritis/vaginitis & NGU, V & 392 & $29 \cdot 0$ & 111 & $15 \cdot 0$ \\
\hline Chancroid & $\mathrm{CH}$ & 2 & $0 \cdot 1$ & 0 & \\
\hline Lympho granuloma venereum & LGV & 2 & $0 \cdot 1$ & 0 & \\
\hline Granuloma inguinale & GI & 1 & 0.1 & 0 & \\
\hline Trichomonas vaginalis & TRI & 9 & 0.7 & 88 & 11.9 \\
\hline Pediculosis & PED & 40 & $3 \cdot 0$ & 6 & 0.8 \\
\hline Scabies & SCA & 17 & $1 \cdot 3$ & 3 & $0 \cdot 4$ \\
\hline Herpes genitalis & $\mathrm{HG}$ & 2 & $0 \cdot 1$ & 1 & $0 \cdot 1$ \\
\hline Candidiasis & CAND & 34 & $2 \cdot 5$ & 156 & $21 \cdot 0$ \\
\hline Psychological & PSY & 13 & $1 \cdot 0$ & 1 & $0 \cdot 1$ \\
\hline Other conditions of genital organs & OTHER & 181 & $13 \cdot 4$ & 72 & $9 \cdot 7$ \\
\hline No disease found & NIL & 341 & $25 \cdot 2$ & 185 & $24 \cdot 9$ \\
\hline Missing information & & 9 & 0.7 & 5 & 0.7 \\
\hline Total & & 1,351 & 100 & 742 & 100 \\
\hline
\end{tabular}


about one-fifth of the population. Twenty boys and 93 girls under the age of 15 years attended the clinic. These were almost all children of infected persons and were brought to the clinic for a check. Only three of them were infected. One girl aged $13 \mathrm{had}$ sexually transmitted gonorrhoea, one female baby had gonorrhoeal ophthalmia, and one boy aged 14 had balano-posthitis. Children under 15 have been omitted from all subsequent tables leaving 1,173 males and 467 females for analysis.

The official returns to the Ministry in Northern Ireland and to that in England and Wales (Department of Health and Social Security, 1970) do not distinguish separate age groups above 25 , although the majority of patients with syphilis and gonorrhoea are over 25 years of age in both areas. While the problem of venereal disease in the teenager and young adult is very important, older men and women are clearly also an important source of infection.

\section{CIVIL STATUS}

Table II shows that the men attending the clinic were more likely than the women to be single and that they were less likely to be widowed, divorced, or separated. The higher proportion of women who were married, compared with the men, is explained by the fact that a large number of married women were brought to the clinic as secondary contacts by husbands who had been infected from a casual extramarital contact. Only 1.6 per cent. of the men and none of the women in the series were non-white.

\section{TYPE OF RESIDENCE}

Table III shows the distribution of patients by type of residence. Nearly two-thirds of the men and three-quarters of the women lived in their parents' home or with their spouse. The high proportion of the women living with their husbands reflects the fact that many come to the clinic as secondary contacts. Sailors constituted an important group of the male patients as is commonly found in sea ports.

\section{EMPLOYMENT AND SOCIAL CLASS}

Of the men, 79 per cent. were employed and 9 per cent. unemployed, 4 per cent. were students, and in 8 per cent. there were no data. These proportions are similar to those found in the Belfast population. When the distributions of the five main diagnostic groups by social class were examined for each sex separately (Table IV, opposite), significant differences were found. Males in Social Classes I and II were less likely to have syphilis, gonorrhoea or 'other conditions' and more likely to have NGU than males in Social Classes III, IV, and V. Women in Social Classes I and II were less likely to have syphilis, gonorrhoea, or NGV than those in the other social classes and were much more likely to have 'Nil'.

\section{SOURCE OF GONORRHOEAL INFECTION}

Table V (opposite) shows the source of infection for the patients with gonorrhoea. The differences are highly significant when married men are compared with married women and single men with single women. The married men were much more likely to have acquired their infection from a casual contact than the married women and similarly the single men were more likely to have acquired their infection from a casual contact than the single women. The same pattern was found in the other diagnostic categories.

TABLE II Distribution by sex and civil status of the 1,640 patients aged 15 and over

\begin{tabular}{|c|c|c|c|c|c|c|}
\hline \multicolumn{2}{|c|}{ Civil Status } & \multirow{2}{*}{$\begin{array}{c}\text { Single } \\
651 \\
55.5\end{array}$} & \multirow{2}{*}{$\begin{array}{l}\text { Married } \\
418 \\
35.6\end{array}$} & \multirow{2}{*}{$\begin{array}{l}\text { Widowed, } \\
\text { divorced, } \\
\text { separated } \\
\frac{50}{4 \cdot 3}\end{array}$} & \multirow{2}{*}{$\begin{array}{l}\begin{array}{l}\text { Missing } \\
\text { information }\end{array} \\
\begin{array}{c}54 \\
4 \cdot 6\end{array}\end{array}$} & \multirow{2}{*}{$\begin{array}{r}\text { Total } \\
1,173 \\
100\end{array}$} \\
\hline Male & $\begin{array}{l}\text { No. } \\
\text { Per cent. }\end{array}$ & & & & & \\
\hline Female & $\begin{array}{l}\text { No. } \\
\text { Per cent. }\end{array}$ & $\begin{array}{c}179 \\
38 \cdot 3\end{array}$ & $\begin{array}{l}221 \\
47 \cdot 3\end{array}$ & $\begin{array}{l}42 \\
9 \cdot 0\end{array}$ & $\begin{array}{l}25 \\
5 \cdot 4\end{array}$ & $\begin{array}{l}467 \\
100\end{array}$ \\
\hline
\end{tabular}

TABLE III Distribution by sex and residence

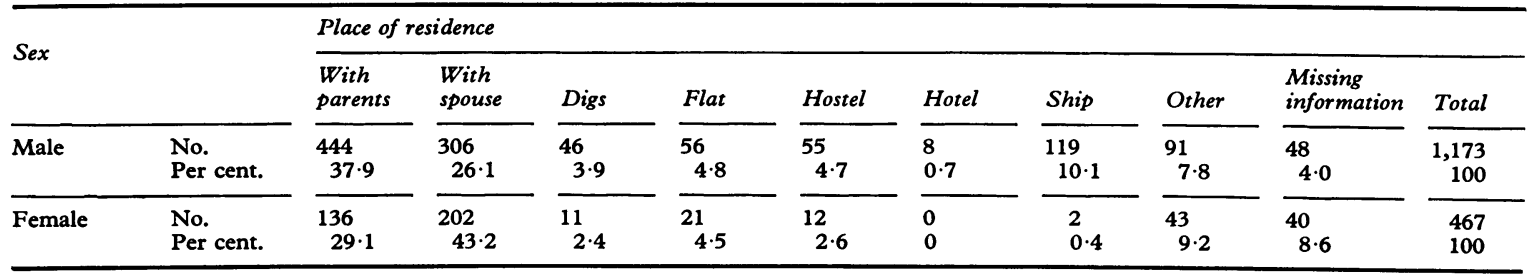


TABLE IV Distribution of male and female patients by social class and diagnosis (excluding 77 students, 44 members of H.M. Forces, and 200 ' missing information')

\begin{tabular}{|c|c|c|c|c|c|c|c|c|c|c|}
\hline \multirow{2}{*}{ Sex } & & & \multicolumn{4}{|l|}{ Male } & \multicolumn{4}{|l|}{ Female } \\
\hline & & & $I$ and $I I$ & $I I I$ & $I V$ and $V$ & Total & $I$ and $I I$ & $I I I$ & $I V$ and $V$ & Total \\
\hline \multirow[t]{6}{*}{ Diagnosis } & Syphilis & $\begin{array}{l}\text { No. } \\
\text { Per cent. }\end{array}$ & $\begin{array}{l}3 \\
1 \cdot 9\end{array}$ & $\begin{array}{l}11 \\
2 \cdot 2\end{array}$ & $\begin{array}{l}19 \\
5 \cdot 7\end{array}$ & $\begin{array}{l}33 \\
3 \cdot 4\end{array}$ & $1 \cdot 5$ & $\begin{array}{l}4 \\
2 \cdot 5\end{array}$ & $\begin{array}{l}3 \\
2 \cdot 8\end{array}$ & $\begin{array}{l}8 \\
2 \cdot 4\end{array}$ \\
\hline & Gonorrhoea & $\begin{array}{l}\text { No. } \\
\text { Per cent. }\end{array}$ & $\begin{array}{l}32 \\
19 \cdot 8\end{array}$ & $\begin{array}{l}129 \\
26 \cdot 4\end{array}$ & $\begin{array}{l}73 \\
21 \cdot 8\end{array}$ & $\begin{array}{l}234 \\
23 \cdot 8\end{array}$ & $\begin{array}{c}9 \\
13 \cdot 6\end{array}$ & $\begin{array}{l}28 \\
17 \cdot 6\end{array}$ & $\begin{array}{l}32 \\
29 \cdot 4\end{array}$ & $\begin{array}{l}69 \\
20 \cdot 7\end{array}$ \\
\hline & NGU/V & $\begin{array}{l}\text { No. } \\
\text { Per cent. }\end{array}$ & $\begin{array}{l}55 \\
34 \cdot 0\end{array}$ & $\begin{array}{l}130 \\
26 \cdot 6\end{array}$ & $\begin{array}{l}81 \\
24 \cdot 3\end{array}$ & $\begin{array}{l}266 \\
27 \cdot 0\end{array}$ & $\stackrel{8}{12 \cdot 2}$ & $\begin{array}{l}42 \\
26 \cdot 4\end{array}$ & $\begin{array}{l}21 \\
19 \cdot 3\end{array}$ & $\begin{array}{l}71 \\
21 \cdot 3\end{array}$ \\
\hline & $\begin{array}{l}\text { Other } \\
\text { conditions }\end{array}$ & $\begin{array}{l}\text { No. } \\
\text { Per cent. }\end{array}$ & $\begin{array}{l}27 \\
16 \cdot 6\end{array}$ & $\begin{array}{l}93 \\
19 \cdot 0\end{array}$ & $\begin{array}{l}72 \\
21 \cdot 6\end{array}$ & $\begin{array}{l}192 \\
19 \cdot 5\end{array}$ & $\begin{array}{l}22 \\
33 \cdot 3\end{array}$ & $\begin{array}{l}59 \\
37 \cdot 1\end{array}$ & $\begin{array}{l}38 \\
34 \cdot 8\end{array}$ & $\begin{array}{l}119 \\
35 \cdot 6\end{array}$ \\
\hline & Nil & $\begin{array}{l}\text { No. } \\
\text { Per cent. }\end{array}$ & $\begin{array}{l}45 \\
27 \cdot 7\end{array}$ & $\begin{array}{l}126 \\
25 \cdot 8\end{array}$ & $\begin{array}{l}89 \\
26 \cdot 6\end{array}$ & $\begin{array}{l}260 \\
26 \cdot 3\end{array}$ & $\begin{array}{l}26 \\
39 \cdot 4\end{array}$ & $\begin{array}{l}26 \\
16 \cdot 4\end{array}$ & $\begin{array}{l}15 \\
13 \cdot 7\end{array}$ & $\begin{array}{l}67 \\
20.0\end{array}$ \\
\hline & Total & $\begin{array}{l}\text { No. } \\
\text { Per cent. }\end{array}$ & $\begin{array}{l}162 \\
100\end{array}$ & $\begin{array}{l}489 \\
100\end{array}$ & $\begin{array}{l}334 \\
100\end{array}$ & $\begin{array}{l}985 \\
100\end{array}$ & $\begin{array}{r}66 \\
100\end{array}$ & $\begin{array}{l}159 \\
100\end{array}$ & $\begin{array}{l}109 \\
100\end{array}$ & $\begin{array}{l}334 \\
100\end{array}$ \\
\hline
\end{tabular}

For males $x^{2}=16.8$ ( 8 d.f.) $0.02<P<0.05$.

For females $x^{2}=27 \cdot 1$ (8 d.f.); $P<0.001$.

TABLE V Distribution of patients with gonorrhoea by source of infection and marital status

\begin{tabular}{|c|c|c|c|c|c|c|c|c|c|c|c|}
\hline \multirow{3}{*}{ Marital stalus } & \multirow{3}{*}{ Sex } & \multicolumn{10}{|c|}{ Source of Infection } \\
\hline & & \multicolumn{2}{|c|}{ Casual } & \multicolumn{2}{|c|}{ Regular } & \multicolumn{2}{|c|}{ Spouse } & \multicolumn{2}{|c|}{ Unknown } & \multicolumn{2}{|c|}{ Total } \\
\hline & & No. & Per cent. & No. & Per cent. & No. & Per cent. & No. & Per cent. & No. & Per cent. \\
\hline $\begin{array}{l}\text { Living with } \\
\text { spouse }\end{array}$ & $\begin{array}{l}\text { Male } \\
\text { Female }\end{array}$ & $\begin{array}{r}76 \\
2\end{array}$ & $\begin{array}{l}76 \\
3 \cdot 2\end{array}$ & $\begin{array}{l}8 \\
5\end{array}$ & $\begin{array}{l}8 \\
7.9\end{array}$ & $\begin{array}{l}16 \\
56\end{array}$ & $\begin{array}{l}16 \\
88 \cdot 9\end{array}$ & $\begin{array}{l}0 \\
0\end{array}$ & $\begin{array}{l}0 \\
0\end{array}$ & $\begin{array}{r}100 \\
63\end{array}$ & $\begin{array}{l}100 \\
100\end{array}$ \\
\hline $\begin{array}{l}\text { Single, } \\
\text { widowed, or } \\
\text { divorced }\end{array}$ & $\begin{array}{l}\text { Male } \\
\text { Female }\end{array}$ & $\begin{array}{r}131 \\
10\end{array}$ & $\begin{array}{l}87 \cdot 3 \\
32 \cdot 3\end{array}$ & $\begin{array}{l}17 \\
21\end{array}$ & $\begin{array}{l}11 \cdot 3 \\
67 \cdot 7\end{array}$ & $=$ & - & $\begin{array}{l}2 \\
0\end{array}$ & $\begin{array}{l}1 \cdot 4 \\
0\end{array}$ & $\begin{array}{r}150 \\
31\end{array}$ & $\begin{array}{l}100 \\
100\end{array}$ \\
\hline \multicolumn{12}{|c|}{$\begin{array}{l}\text { Exclusions: One female under } 15, \text { six males, and two females marital status unknown. } \\
\varkappa^{2}(M / F \text { living with spouse })=89 \cdot 3(2 \text { d.f. }) ; P<0.001 \\
\left.\varkappa^{2}(M / F \text { single })=48 \cdot 5 \text { ( } 2 \text { d.f. }\right) ; P<0.001\end{array}$} \\
\hline \multicolumn{6}{|c|}{$\begin{array}{l}\text { HOMOSEXUAL SOURCE OF INFECTION } \\
\text { Of } 1,173 \text { male patients, fourteen ( } 1 \cdot 2 \text { per cent.) } \\
\text { admitted to a possible homosexual source of infection. } \\
\text { Of these, two had secondary syphilis, one gonorrhoea, } \\
\text { and two NGU, and in nine no disease was found. }\end{array}$} & \multicolumn{6}{|c|}{$\begin{array}{l}\text { cent.) and the dance hall ( } 22 \cdot 0 \text { per cent.). In the case } \\
\text { of those women to whom the question was applicable, } \\
\text { the commonest meeting place mentioned was the } \\
\text { dance hall ( } 19 \cdot 1 \text { per cent.). Only } 5 \cdot 1 \text { per cent. } \\
\text { mentioned the public house. There was a large } \\
\text { miscellaneous category of meeting places, including }\end{array}$} \\
\hline
\end{tabular}

TABLE VI Distribution of patients by sex and meeting place

\begin{tabular}{|c|c|c|c|c|c|c|c|c|c|c|c|}
\hline Sex & & House & Street & $\begin{array}{l}\text { Dance } \\
\text { hall }\end{array}$ & $\begin{array}{l}\text { Public } \\
\text { house }\end{array}$ & Party & $C l u b$ & $\begin{array}{l}\text { Public } \\
\text { transport }\end{array}$ & Miscellaneous & $\begin{array}{l}\text { Missing } \\
\text { information }\end{array}$ & Total \\
\hline Male & $\begin{array}{l}\text { No. } \\
\text { Per cent. }\end{array}$ & $\begin{array}{l}21 \\
2 \cdot 1\end{array}$ & $\begin{array}{l}98 \\
9 \cdot 8\end{array}$ & $\begin{array}{r}220 \\
22 \cdot 0\end{array}$ & $\begin{array}{l}260 \\
26 \cdot 1\end{array}$ & $\begin{array}{l}82 \\
8 \cdot 2\end{array}$ & $\begin{array}{l}37 \\
3 \cdot 7\end{array}$ & $\begin{array}{l}9 \\
0.9\end{array}$ & $\begin{array}{l}196 \\
19 \cdot 6\end{array}$ & $\begin{array}{l}76 \\
7 \cdot 6\end{array}$ & $\begin{array}{l}999 \\
100\end{array}$ \\
\hline Female & $\begin{array}{l}\text { No. } \\
\text { Per cent. }\end{array}$ & $\begin{array}{l}11 \\
4 \cdot 7\end{array}$ & $\begin{array}{l}6 \\
2 \cdot 6\end{array}$ & $\begin{array}{l}45 \\
19 \cdot 1\end{array}$ & $\begin{array}{l}12 \\
5 \cdot 1\end{array}$ & $\begin{array}{l}10 \\
4 \cdot 3\end{array}$ & $\begin{array}{l}1 \\
0 \cdot 4\end{array}$ & $\begin{array}{l}2 \\
0.9\end{array}$ & $\begin{array}{r}122 \\
51 \cdot 9\end{array}$ & $\begin{array}{l}26 \\
11 \cdot 0\end{array}$ & $\begin{array}{l}235 \\
100\end{array}$ \\
\hline Total & $\begin{array}{l}\text { No. } \\
\text { Per cent. }\end{array}$ & $\begin{array}{l}32 \\
2 \cdot 6\end{array}$ & $\begin{array}{r}104 \\
8 \cdot 4\end{array}$ & $\begin{array}{l}265 \\
21 \cdot 5\end{array}$ & $\begin{array}{l}272 \\
22 \cdot 0\end{array}$ & $\begin{array}{l}92 \\
7 \cdot 5\end{array}$ & $\begin{array}{l}38 \\
3 \cdot 1\end{array}$ & $\begin{array}{l}11 \\
0.8\end{array}$ & $\begin{array}{l}318 \\
25 \cdot 8\end{array}$ & $\begin{array}{r}102 \\
8 \cdot 3\end{array}$ & $\begin{array}{r}1,234 \\
100\end{array}$ \\
\hline
\end{tabular}

174 men and 232 women excluded as not applicable e.g. spouse, blood transfusion referral, etc. 
For 406 patients, the questions relating to meeting place and alcohol consumption were inapplicable. These were those who contracted their infection from their spouse or who were referred from other clinics or from the blood transfusion service because of a positive serological reaction.

\section{PLACE OF INTERCOURSE}

Table VII shows the distribution of patients by sex and place of intercourse (excluding infection from spouse and referrals, see above). In addition to those places shown in the Table, 27 other types of location were mentioned, and are included under the heading 'Other'. These included such places as barn (4), tent (3), dance hall (1), at work (2), beach (3), baby-sitting (1), and park (4). Eleven men but no women said they had acquired their infection in a brothel (4 in foreign countries). It is noteworthy that a far higher proportion of men than women mentioned the street, a ship, or a brothel as the place of intercourse.

\section{PAYMENT OF THE WOMEN}

Of the 1,003 men to whom this question was applicable, 16.9 per cent. said they had paid money to the women. Of the women to whom it was applicable, only 0.8 per cent. said that a cash payment had been made.

\section{USE OF SHEATH}

The men were asked whether they used a sheath or not, and the distributions by diagnosis and use of sheath were examined. Table VIII shows that there was a significant difference in the distributions. In those who used a sheath the proportion with syphilis or gonorrhoea was lower, and the proportion with NGU or Nil was higher. The apparent failure of the use of a sheath to reduce the risk of NGU is noteworthy. When the men who used, or did not use, a sheath, were analysed by social class, it was found that $14 \cdot 2$ per cent. of men in Social Classes I and II said they used a sheath compared with 10.8 per cent. in Social Class III and 7.6 per cent in Social Classes IV and V.

\section{EXAMINATION OF CONTACTS OF PATIENTS WITH GONORRHOEA AND NGU}

Of the 256 men with gonorrhoea, 119 (47 per cent.) said they could identify their source of infection and were given contact slips. Only 45 women attended

TABLE VII Distribution of patients by place where intercourse took place

\begin{tabular}{|c|c|c|c|c|c|c|c|c|c|c|c|}
\hline Sex & & $\begin{array}{l}\text { Residence } \\
\text { of } \\
\text { male }\end{array}$ & $\begin{array}{l}\text { Residence } \\
\text { of } \\
\text { female }\end{array}$ & $\begin{array}{l}\text { Other } \\
\text { residencz }\end{array}$ & Car & Street & Hotel & Ship & Other & $\begin{array}{l}\text { Missing } \\
\text { information }\end{array}$ & Total \\
\hline Male & $\begin{array}{l}\text { No. } \\
\text { Per cent. }\end{array}$ & $\begin{array}{l}99 \\
9 \cdot 9\end{array}$ & $\begin{array}{l}249 \\
24 \cdot 7\end{array}$ & $\begin{array}{l}60 \\
6.0\end{array}$ & $\begin{array}{l}229 \\
22 \cdot 8\end{array}$ & $\begin{array}{l}113 \\
11 \cdot 2\end{array}$ & $\begin{array}{l}37 \\
3 \cdot 7\end{array}$ & $\begin{array}{l}52 \\
5 \cdot 2\end{array}$ & $\begin{array}{l}88 \\
8 \cdot 8\end{array}$ & $\begin{array}{c}78 \\
7 \cdot 8\end{array}$ & $\begin{array}{r}1,005 \\
100\end{array}$ \\
\hline Female & $\begin{array}{l}\text { No. } \\
\text { Per cent. }\end{array}$ & $\begin{array}{l}54 \\
23.0\end{array}$ & $\begin{array}{l}67 \\
28 \cdot 5\end{array}$ & $\begin{array}{l}17 \\
7 \cdot 2\end{array}$ & $\begin{array}{l}43 \\
18 \cdot 3\end{array}$ & $\begin{array}{l}2 \\
0.9\end{array}$ & $\begin{array}{l}8 \\
3 \cdot 4\end{array}$ & $\begin{array}{l}3 \\
1 \cdot 3\end{array}$ & $\begin{array}{l}16 \\
6 \cdot 8\end{array}$ & $\begin{array}{l}25 \\
10 \cdot 6\end{array}$ & $\begin{array}{l}235 \\
100\end{array}$ \\
\hline Total & $\begin{array}{l}\text { No. } \\
\text { Per cent. }\end{array}$ & $\begin{array}{l}153 \\
12 \cdot 3\end{array}$ & $\begin{array}{l}316 \\
25 \cdot 5\end{array}$ & $\begin{array}{l}77 \\
6 \cdot 2\end{array}$ & $\begin{array}{l}272 \\
21 \cdot 9\end{array}$ & $\begin{array}{l}115 \\
9 \cdot 3\end{array}$ & $\begin{array}{l}45 \\
3 \cdot 6\end{array}$ & $\begin{array}{l}55 \\
4 \cdot 4\end{array}$ & $\begin{array}{r}104 \\
8 \cdot 4\end{array}$ & $\begin{array}{r}103 \\
8.4\end{array}$ & $\begin{array}{r}1,240 \\
100\end{array}$ \\
\hline
\end{tabular}

168 men and 232 women excluded because the question was not applicable.

TABLE VII Distribution of male patients by diagnosis and by use of sheath

\begin{tabular}{|c|c|c|c|c|c|}
\hline \multicolumn{2}{|l|}{ Diagnosis } & \multirow{2}{*}{$\begin{array}{c}\text { Sheath } \\
1 \\
0.9\end{array}$} & \multirow{2}{*}{$\begin{array}{l}\text { No sheath } \\
23 \\
2 \cdot 7\end{array}$} & \multirow{2}{*}{$\begin{array}{l}\text { Not applicable } \\
\text { or } \\
\text { Missing information }\end{array}$} & \multirow{2}{*}{$\begin{array}{r}\text { Total } \\
51\end{array}$} \\
\hline Syphilis & $\begin{array}{l}\text { No. } \\
\text { Per cent. }\end{array}$ & & & & \\
\hline Gonorrhoea & $\begin{array}{l}\text { No. } \\
\text { Per cent. }\end{array}$ & $\begin{array}{l}15 \\
13 \cdot 4\end{array}$ & $\begin{array}{l}224 \\
26 \cdot 2\end{array}$ & 17 & 256 \\
\hline NGU & $\begin{array}{l}\text { No. } \\
\text { Per cent. }\end{array}$ & $\begin{array}{l}39 \\
34 \cdot 8\end{array}$ & $\begin{array}{l}249 \\
29 \cdot 1\end{array}$ & 23 & 311 \\
\hline $\begin{array}{l}\text { Other } \\
\text { Conditions }\end{array}$ & $\begin{array}{l}\text { No. } \\
\text { Per cent. }\end{array}$ & $\begin{array}{l}22 \\
19 \cdot 6\end{array}$ & $\begin{array}{l}148 \\
17 \cdot 3\end{array}$ & 63 & 233 \\
\hline Nil & $\begin{array}{l}\text { No. } \\
\text { Per cent. }\end{array}$ & $\begin{array}{l}35 \\
31 \cdot 3\end{array}$ & $\begin{array}{l}211 \\
24 \cdot 7\end{array}$ & 76 & 322 \\
\hline Total & $\begin{array}{l}\text { No. } \\
\text { Per cent. }\end{array}$ & $\begin{array}{l}112 \\
100\end{array}$ & $\begin{array}{l}855 \\
100\end{array}$ & 206 & 1,173 \\
\hline
\end{tabular}

$x^{2}=10.93$ (4d.f.); $P<0.02$ ). 
the clinic as a result of the issue of these contact slips. A similar result was achieved for cases of NGU.

The figures indicate that many men with gonorrhoea or NGU are either unwilling or unable to seek out the woman from whom they may have acquired the infection and to persuade her to attend the clinic. They also confirm the belief that there is a group of women who, in casual relationships, transmit these infections to the men who attend the clinic but who do not themselves attend, possibly because they are unaware that they are infected.

\section{Discussion}

It should be emphasized that much of the data in this study was derived from answers given by patients. Although we have no evidence that untrue statements were made, it may be expected that questions about venereal disease, and particularly about the circumstances under which it is acquired, may not always be answered truthfully. With these reservations there are nevertheless some findings which seem to be of importance with regard to the control of these diseases. Firstly, only 24 per cent. of all the patients were found to have the 'statutory' venereal diseases, syphilis, gonorrhoea, or chancroid. This is the same proportion as in England in 1969 (Department of Health and Social Security, 1970).

Although the majority of patients reporting to V.D. clinics are over 25 years of age in Northern Ireland as in Great Britain, there is some evidence from Great Britain that the incidence is rising disproportionately in the younger age groups (Department of Health and Social Security, 1970). There is therefore an urgent need to bring the facts about V.D. to the notice of older school children and young adults. This should be done by more extensive health education in schools, colleges, and youth clubs. In this series of cases the public house was the common. est place for the man to meet his partner, followed by the dance hall. Wells and Schofield (1970) found the same for men (all ages), though for the younger ages the dance hall was the commonest place. He does not give figures for females. In our series the dance hall was the commonest meeting place mentioned by female patients. For this reason attempts should be made to have information about V.D. displayed more widely in the cloakrooms and lavatories of public houses and dance halls. The Health Education Unit of the Scottish Home and Health Department (1970) has made some suggestions with regard to the wording of such notices. It is important that they should be legible, interesting, and compelling.

In Belfast, as in England and Wales, more than twice as many men as women attend the V.D. clinics. It could be argued that a small number of infected women are infecting a much larger number of men, and this is known on occasion to take place, but there is a good deal of circumstantial evidence that many infected women do not come to the clinics. The very high proportion of men who stated that their infection was derived from a casual contact, taken with the low proportion of women who said that their infection was derived in this way (Table V), suggests the existence of a pool of promiscuous infected women, many of whom do not seek treatment at the clinics. Similarly, the much greater proportion of men compared with women patients who met their consort at a public house (Table VI), who had intercourse in the street or on a ship (Table VII) or in a brothel, or who stated that there was a cash payment involved, is further evidence of the existence of a group of women who tend not to come to the clinic. Perhaps the most important reason why many women with gonorrhoea do not come to the V.D. clinics is because they often have only minor symptoms, or none. Dunlop (1963) showed that, in a series of 100 consecutive cases of gonorrhoea in women, 69 came to the clinic because their consort had developed a discharge, while only 22 came because they had symptoms themselves. Mahony (1972) reported that only two out of 130 women with gonorrhoea were motivated to attend the clinic because of symptoms.

The problem of identifying contacts, particularly those women who are the source of infection of the men, and of persuading them to come for examination is one of great importance for preventing the further spread of these diseases.

\section{Summary}

Medical and social data were collected on all the patients attending the venereal disease clinic at the Royal Victoria Hospital, Belfast, for one year. An analysis of the diagnoses showed that the majority of patients were suffering from diseases other than the statutory venereal diseases or had no disease. The men were more likely to be single and to have acquired their condition from a casual contact than the women, and there were significant differences in the frequency of the diseases by social class. There were considerable differences between the meeting places and places where intercourse took place as stated by the men compared with the women.

The findings strongly suggest that there is a group of women, the casual primary contacts of the men, who are less likely to come to the clinic than the wives who come as secondary contacts of their 
infected husbands. The importance of identifying the 'missing' women and persuading them to come to the clinic for treatment, and of disseminating information about sexually transmitted disease, especially to young people, is emphasized.

\section{References}

Department of Health AND Social Security (1970)

'Annual Report of the Chief Medical Officer for 1969,' p. 57 and Appendix C. H.M.S.O., London

Dunlop, E. M. C. (1963) Brit. F. vener. Dis., 39, 109

Health Education Unit, Scottish Home and Health Department (1970) Hlth Bull. (Edinb.), 28, no. 1, p. 6

MaHony, J. D. H. (1972) Brit. F. vener. Dis., 48, 71

Wells, B. P. W., and Schofield, C. B. S. (1970) Hlth

Bull. (Edinb.), 28, no. 1, p. 75

Caractéristiques socio-médicales des malades fréquentant une clinique antivénérienne et circonstances de l'infection

Pendant une année on a recueilli des informations médicales et sociales pour tous les malades se présentant à la clinique antivénérienne du Royal Victoria Hospital, Belfast. Une analyse des diagnostics montra que la plupart des malades étaient atteints de maladies autres que les maladies vénériennes officielles, ou qu'ils n'avaient aucune maladie. Les hommes étaient, plus souvent que les femmes, célibataires et ayant acquis leur affection lors d'un contact occasionnel; des différences significatives furent trouvées dans la fréquence des maladies selon la classe sociale. Par rapport aux femmes, il y eut chez les hommes des différences considérables quant aux endroits de la rencontre et du rapport sexuel.

Ces constatations font fortement penser qu'il y a un groupe de femmes, auprès desquelles les hommes se contaminent occasionnellement, qui ont moins tendance à venir à la clinique que les femmes légitimes, contacts secondaires de leurs maris infectés. On insiste sur l'importance qu'il y a d'identifier les femmes manquantes et de les persuader de venir se faire traiter à la clinique; on insiste aussi sur la nécessité de diffuser des informations sur les maladies sexuelles, en particulier auprès de la jeunesse. 